International Journal of Medical Sciences

ISSN 1449-1907 www.medsci.org 2008 5(1):36-40

Research Paper

(C) Ivyspring International Publisher. All rights reserved

\title{
Correlation of the Radiographic and Morphological Features of the Dental Follicle of Third Molars with Incomplete Root Formation
}

\section{David Moraes de OLIVEIRA', Emanuel Sávio de Souza ANDRADE², Márcia Maria Fonseca da SILVEIRA², Igor Batista CAMARGO1}

1. Postgraduation Program of Oral and Maxillofacial Surgery - School of Dentistry of Pernambuco (FOP/UPE), Brazil.

2. Department of Oral Medicine, University of Pernambuco, Camaragibe - Pernambuco - Brazil.

Correspondence to: Prof. Dr. Emanuel Sávio de Souza Andrade, Departamento de Medicina Oral - Disciplina de Patologia Bucal, Faculdade de Odontologia de Pernambuco - FOP/UPE, Av. General Newton Cavalcanti, 1650, 54753-220 Camaragibe, PE, Brazil. Tel. / Fax:+55-81-3458-6758; E-mail: savio@fop.upe.br/igorildo@hotmail.com/igorbc-cirurgia@fop.upe.br

Received: 2007.12.26; Accepted: 2008.01.29; Published: 2008.02.08

The objective of this study was to determine the correlation of the radiographic and morphological features of the dental follicle of unerupted third molars with incomplete root formation. A cross-sectional study was carried out with 56 patients (105 teeth) aged 13 to 24 years. Panoramic radiography was used to determine the stage of root formation to locate and measure pericoronal radiolucency. The width of the dental follicle ranged from 0.0 to 4.0 $\mathrm{mm}$, the distal face being the one most frequently involved, and stage 7 of root formation showing the highest incidence. An inactive enamel reduced epithelium and inactive epithelium remnant also showed a high incidence. Dense connective tissue showed a high incidence, chronic inflammation was infrequent and calcification was a common finding. There was a significant association between the progression of the rhizogenesis and the transformation of the enamel reduced epithelium into a stratified squamous epithelium. No significant association was found between rhizogenesis and the other morphological findings or between the latter and the width of the pericoronal space. It was concluded that there was no clinically significant correlation between the radiographic and morphological features. Every asymptomatic unerupted third molar should be followed up and the follicular tissue analyzed.

Key words: Molar Third/surgery, Molar Third/radiography, Molar Third/physiopathology, Dental Sac/physiopathology, Dental Sac/radiography

\section{INTRODUCTION}

The formation of a tooth occurs inside a development sac known as the dental follicle or dental sac, which surrounds the papilla of the tooth and the enamel organ [1]. Damante [2] characterized the follicle as being the remnant of the tissues that participated in the odontogenesis and remained circumjacent to the crown of a tooth whose normal eruption has not occurred, the wall of connective tissue and the odontogenic epithelial remnants distributed in this tissue being its main constituents. The follicle is responsible for the formation of the periodontal ligament and cement [3]. Saap et al. [4] report that the follicle becomes part of the connective tissue of the free marginal gum and Cahill and Marks [5] have demonstrated its importance in the process of eruption.

Consolaro [6] states that the potential transformation of unerupted teeth into cystic or neoplastic ones is related to the constituent structures of the follicle, in particular, the enamel reduced epithelium and remnants of dental lamina located in its connective tissue wall. Histologically, the follicular tissues may be confused with pathosis, correlations of the clinical, radiographic and histopathological findings being required to establish a diagnosis [3].

Radiographically, the pericoronal follicles present as slight semicircular radiolucencies around unerupted teeth; however, enlargements or asymmetries can occur, which may be misinterpreted [3]. For Santamaria and Artegoitia [7], pericoronal radiolucency is one of the most important factors to be borne in mind in the decision on whether to retain or remove an impacted tooth, and the presence of radiolucency may be the only indication for this procedure. Despite the importance of the radiographic findings, Miller and Bean [8] state that disease conditions may be found in minute follicular spaces and in enlarged radiolucent areas there may be histologically normal tissues, so a biopsy is imperative.

Taking into consideration that the radiograph is in most cases the only instrument available to the oral and maxillofacial surgeon for deciding between removing or following up an asymptomatic unerupted 
tooth and that a number of studies show the possibility of cystic degeneration and/or neoplastic transformation of the follicles, the present study evaluated the correlation between radiographic and morphologic features of pericoronal follicles of unerupted third molars with incomplete rhizogenesis, with the aim of acquiring insights that might aid a surgeon faced with such teeth.

\section{MATERIAL AND METHODS}

The sample consisted of 56 patients, of whom 17 (30\%) were males and $39(70 \%)$ were females, with a total of 105 follicles of unerupted third molars with incomplete rhizogenesis. Ages ranged from 13 to 24 years, with a mean of 18.3 years (standard deviation $=$ 2.7 years) and a median of 18 years. This is a cross-sectional study in which the sample was established within a specific time frame. The study was approved by the Ethics in Research Committee of the State University of Pernambuco.

The type of radiograph used was the panoramic one, only teeth between Nolla's [9] stages 6 (complete crown) and 9 (almost complete root, open apex) of rhizogenesis being included in the study. The width of the pericoronal space was determined from the half of the mesial, distal and occlusal surfaces, the largest width being selected. The harvesting of the follicle was performed by separation at the level of the cementoenamel junction, with the follicle being conditioned in $10 \%$ formol. The specimens were submitted to the routine histotechnical procedures, semi-serial cross-sections with a thickness of $5 \mu \mathrm{m}$, being selected and stained with hematoxylin-eosin (HE). All examinations were carried out by a single professional.

The odontogenic lining epithelium was classified according to cell activity as inactive, hyperplastic and absent. It was considered inactive when it presented fewer than 20 layers of epithelial cells and when there were no epithelial projections into the connective tissue. It was considered hyperplastic when there were over 20 layers or epithelial projections. Regarding type, it was classified as enamel reduced epithelium and stratified squamous epithelium $[2,6]$.

The remaining epithelium in the connective tissue was classified as inactive, proliferative or absent. It was inactive when exhibiting a typical island or string formation and proliferative when forming sheets or layers of cells [10]. In the evaluation of the connective tissue an analysis was made of the type to verify whether it was dense or loose and whether inflammation was present, the latter being classified as acute, chronic or absent. The presence of calcification was also recorded.

The data were analyzed using absolute and relative frequencies. The Pearson chi-square test with a significance level of $5 \%$ was employed to assess the correlation between the radiographic and morphological features.

\section{RESULTS AND DISCUSSION}

In the correlation between the type of lining epithelium and the stage of rhizogenesis (Table 1), it was found that the enamel reduced epithelium (Figure 1 ) was the most commonly found type at all stages of rhizogenesis; however, at stages 8 and 9 there was a marked increase in follicles with stratified squamous epithelium (Figure 2), probably owing to a greater maturation of this follicle, such a transformation being expected.

Table 1. Distribution of type of lining epithelium according to stage of rhizogenesis

\begin{tabular}{|c|c|c|c|c|c|c|c|c|}
\hline & \multicolumn{9}{c}{ Type of lining epithelium } \\
\hline & \multicolumn{2}{c|}{ Absent } & \multicolumn{2}{c|}{ SSE } & \multicolumn{2}{c|}{ ERE } & \multicolumn{2}{c|}{ Total } \\
\hline Stage of rhizogenesis & $\mathrm{N}$ & $\%$ & $\mathrm{~N}$ & $\%$ & $\mathrm{~N}$ & $\%$ & $\mathrm{~N}$ & $\%$ \\
\hline \# 6 & 2 & 20.0 & 0 & 0.0 & 8 & 80.0 & 10 & 100.0 \\
\hline \# & 7 & 18.9 & 1 & 2.7 & 29 & 78.4 & 37 & 100.0 \\
\hline \# 8 & 5 & 19.2 & 5 & 19.2 & 16 & 61.5 & 26 & 100.0 \\
\hline Total & 10 & 31.3 & 9 & 28.1 & 13 & 40.6 & 32 & 100.0 \\
\hline & 24 & 22.9 & 15 & 14.3 & 66 & 62.9 & 105 & 100.0 \\
\hline
\end{tabular}

${ }^{*} \mathrm{p}$ value $=0,017$ (Pearson chi-square)

$\mathrm{N}=$ Number of teeth

SSE $=$ Stratified Squamous Epithelium

$\mathrm{ERE}=$ Enamel Reduced Epithelium

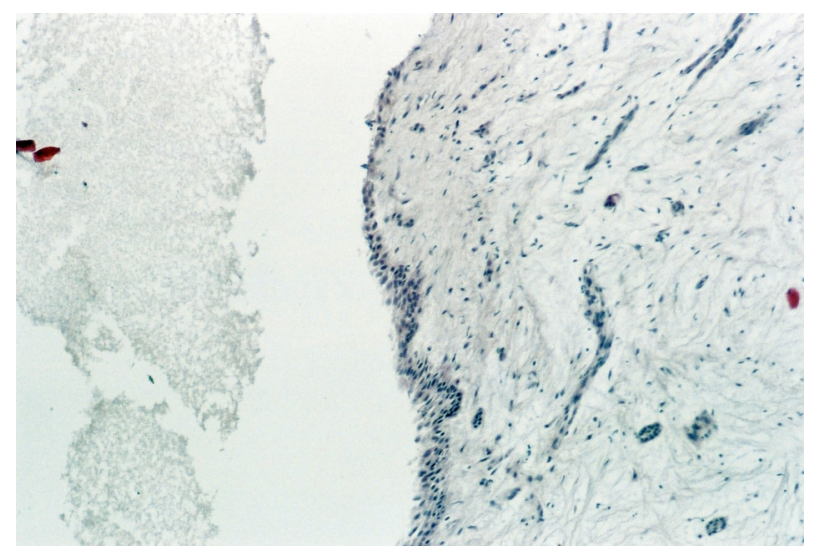

Figure 1. Inactive enamel reduced epithelium (HE / 100X) 


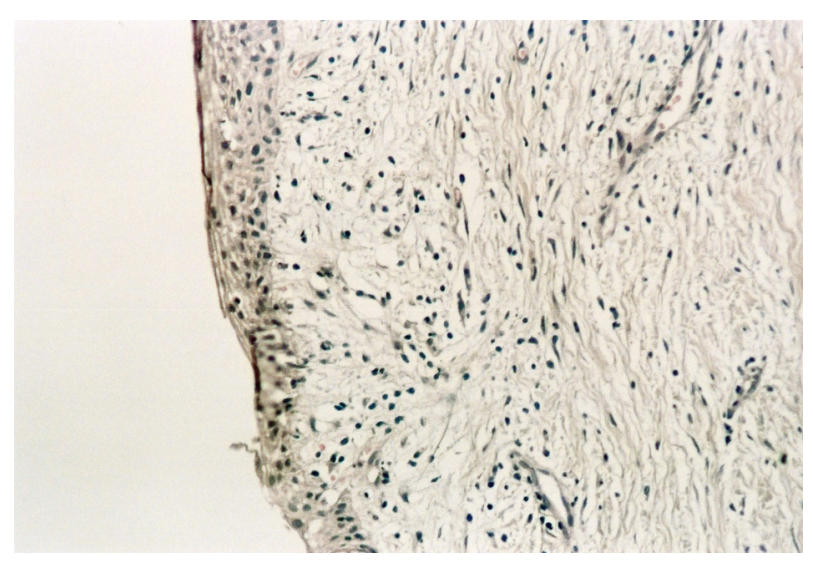

Figure 2. Inactive stratified squamous epithelium and mild chronic inflammation in the connective tissue (HE / 200X)

At stage 7 of rhizogenesis, proportionally, the occurrence of stratified squamous epithelium $(2.7 \%)$ was less than expected and that of enamel reduced epithelium $(78.4 \%)$ greater than what was to be expected, namely $14.3 \%$ and $62.9 \%$, respectively. At stage 9 the presence of squamous epithelium (28.1\%) was more frequent than expected and that of reduced epithelium $(40.6 \%)$ less frequent than expected. These data prove that the transformation of the reduced epithelium into squamous epithelium with maturation of the follicle and consequently with increasing age was statistically significant $(\mathrm{p}=0.017)$.

These findings corroborate those of Daley and Wysocki [11], who state that the normal follicle may be lined by squamous epithelium and that a dentigerous cyst probably develops when the reduced epithelium is still present, which is at variance with Glosser and Campbell [12] and Curran et al. [13], who argue that any follicle with squamous epithelium should be regarded as a dentigerous cyst. According to Slater [14], the presence of squamous epithelium cannot be diagnosed as a dentigerous cyst, but rather as follicular tissue with squamous differentiation. On the basis of these criteria, no dentigerous cyst was diagnosed in the present study.

The use of immunohistochemistry in the study of follicles has led to greater discussion of this controversial question, since Adelsperger et al. [15] demonstrated an association between squamous differentiation and proliferative activity in the majority of cases. The authors disagree with the view that squamous metaplasia is a normal change that takes place during the maturation of the follicle and state that it represents an early pathosis, a stance supported by the proliferating cell nuclear antigen (PCNA).

In the correlation between the type of lining epithelium and the width of the radiographic pericoronal space, there was no statistically significant difference ( $p=0.353)$; it was, however, noted that the pericoronal space was observed even in most of the follicles with no epithelium. The predominant widths were 0 to $1 \mathrm{~mm}(20.7 \%)$ and 3 to $4 \mathrm{~mm}(77.8 \%)$ in the stratified squamous epithelium and reduced epithelium, respectively. These results were totally different to those of Damante and Fleury [16], who found a statistically significant association between the presence of stratified squamous epithelium and an enlarged pericoronal space.

In the correlation between the cellular activity of the lining epithelium and the stage of rhizogenesis, there was no statistical significance $(p=0.702)$; at stage 9, however, proportionally, there was a tendency for cellular activity to be absent $(31.3 \%)$, compared with what was expected (22.9\%), which may be due to the maturation of the follicles. In the correlation between cellular activity of the epithelium and width of the pericoronal space, there was no statistical significance $(p=0.825)$, but there was a tendency for the width to be less than $3 \mathrm{~mm}$ in the hyperplastic epithelium (Figures 3,4 ), a result at variance with what had been expected.

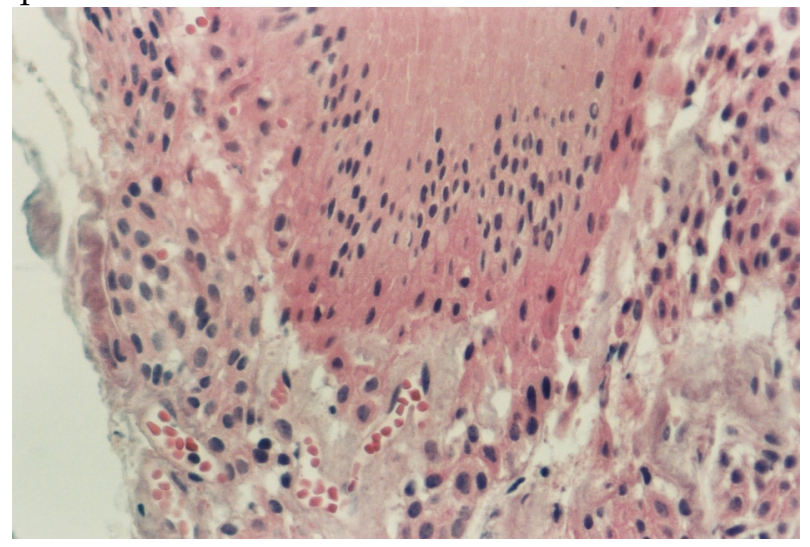

Figure 3. Specimen exhibiting hyperplastic enamel reduced epithelium (HE / 400X)

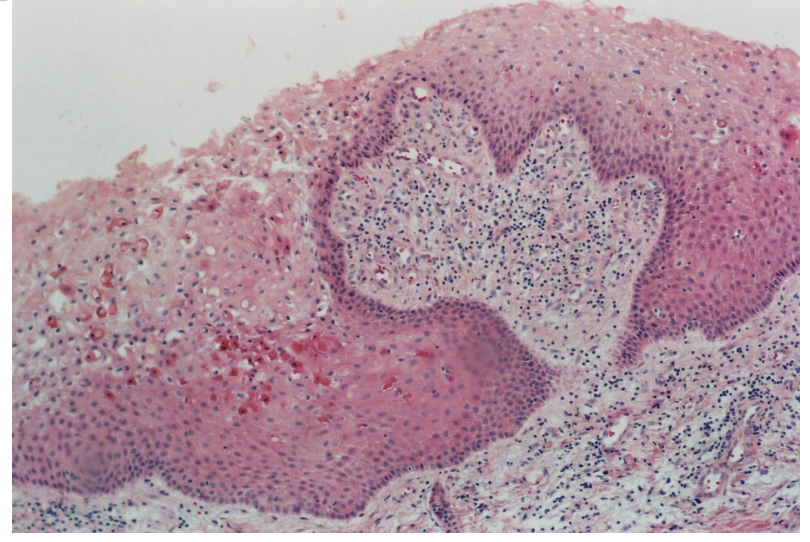

Figure 4. Specimen exhibiting hyperplastic stratified squamous epithelium and chronic inflammation in the connective tissue, on which islands of inactive odontogenic epithelium are seen (HE / 100X) 
In the correlation between the type of connective tissue and the stage of rhizogenesis, there was no statistical significance $(p=0.212)$; at stage 8 , however, dense connective tissue $(57.7 \%)$ tended to occur less frequently and loose tissue $(42.3 \%)$ more frequently than expected, namely $72.4 \%$ and $27.6 \%$, respectively. At stage 7 , dense connective tissue $(81.1 \%)$ occurred more frequently and loose tissue $(18.9 \%)$ less frequently, differently from the results expected. In the correlation between the type of connective tissue and the width of the pericoronal space, there was no statistical significance $(p=0.364)$.

In the correlation between inflammation in the connective tissue and stage of rhizogenesis there was no statistical difference $(p=0.104)$, but no follicle exhibited inflammation at stage 6 . At stage 9 , there was a greater occurrence of chronic inflammation (31.3\%) and the absence of inflammation $(68.8 \%)$ was less frequent than expected, namely $20.0 \%$ and $80.0 \%$, respectively, showing clearly that the earlier the rhizogenesis and the more intra-osseous the tooth, the less the inflammation. The presence of inflammation increased with the progression of the rhizogenesis, and this may be due to the physiology of eruption or proximity to the oral environment [16].

In the correlation between inflammation of the connective tissue and width of the pericoronal space, there was no statistical significance $(p=0.439)$, but there was a tendency for the absence of inflammation up to $1.0 \mathrm{~mm}$, the presence of chronic inflammation from $1.5 \mathrm{~mm}$ to $2.5 \mathrm{~mm}$ and the absence of inflammation between $3.0 \mathrm{~mm}$ and $4.0 \mathrm{~mm}$. These results are at variance with those of Damante and Fleury [16], who found an association between inflammation and an enlargement of the pericoronal space despite the lack of statistical significance.

It was also observed that in $4.8 \%$ of the follicles the following changes occurred that deviated from the pattern of normality: proliferative sheets and layers of epithelium; islands of epithelium in the connective tissue with squamous metaplasia; islands of epithelium with squamous metaplasia and an area suggestive of cystic degeneration; islands with an ameloblastomatoid feature; and an island suggestive of cystic degeneration. Costa Filho [17] identified remnants of epithelium in the connective tissue in $98 \%$ of the specimens evaluated, only $2 \%$ of which had proliferative cellular activity. Kim and Ellis [3] found traces of epithelium in the connective tissue in $79 \%$ of the cases studied and foci of squamous metaplasia in the remnants of epithelium in $4 \%$ of the sample. The presence of islands with an ameloblastomatoid feature was reported in dentigerous cysts by Garrocho et al. [18] and in follicles by Andrade [10], and cystic degeneration by Andrade [10]. Patients with such changes should be followed up radiographically, hence the importance of the histopathology examination of the pericoronal follicles.

In addition to the evaluation of statistical data, clinical experience is of fundamental importance in the management of asymptomatic unerupted third molars in relation to whether or not they need to be removed. Even though, statistically, most studies suggest that the possibility of pathological changes is only a small one, it does exist.

Assael [19] reported his personal analysis of the elective removal of impacted teeth based on the articles of Curran et al. (2002); Kugelberg (1990); Kugelberg et al. (1985); Rood; Shehab (1990). The study by Curran et al. served to show that the early removal of impacted teeth is usually desirable and that their preservation requires long-term follow-up. With regard to the studies of Kugelberg and Kugelberg et al., Assael concluded that, owing to the risk of bone loss and slower healing, in patients over the age of 25 years impacted teeth should be removed only if they exhibit clinical or radiographic signs of a pathosis. Evaluating the work of Rood; Shehab, he observed that teeth with completely formed roots have a greater potential for causing an injury to the inferior alveolar nerve and should be removed prior to the closure of the apex. He concluded that an indication for the prophylactic removal of impacted teeth is based in part on the significant risk of destructive pathoses associated with the follicular tissues.

As yet it does not seem possible to confidently determine which unerupted third molars, whether radiographically normal or not, but with histological evidence of cyst formation or another pathosis, may turn into clinically detectable lesions. Further studies are thus required with a view to calculating the risks involved when a decision is taken not to remove an asymptomatic unerupted third molar.

On the basis of the results obtained and the methodology employed, it is concluded that there was an association between the progression of rhizogenesis and the transformation of the enamel reduced epithelium into stratified squamous epithelium, which was regarded as a normal finding. There were no clinically significant association between the radiographic and morphological findings; accordingly, all asymptomatic unerupted third molars should be submitted to radiographic follow-up and any follicle obtained from such teeth should be sent for a histopathology investigation.

\section{ACKNOWLEDGEMENTS}

The authors wish to thank the Pernambuco State Foundation for the Support of Science and Technology 
(FACEPE) for its financial support.

\section{Conflict of interests}

The authors have stated that no conflict of interest exists.

\section{REFERENCES}

1. Bhaskar SN. Histologia e embriologia oral de Orban, 10th ed. São Paulo: Artes Médicas; 1989.

2. Damante JH. Estudo dos folículos pericoronários de dentes não irrompidos e parcialmente irrompidos; Inter-relação clínica, radiológica e microscópica [Doctoral Thesis]. Bauru: Faculdade de Odontologia de Bauru, Universidade de São Paulo. 1987.

3. Kim J, Ellis GL. Dental follicle tissue: Misinterpretation as odontogenic tumors. J Oral Maxillofac Surg 1993;51:762-767.

4. Sapp JP, Eversole LR, Wisocki GP. Contemporary oral and maxillo-facial pathology. Missouri: Mosby; 1997.

5. Cahill DR, Marks SC. Tooth eruption: evidence for the central role of the dental follicle. J Oral Pathol 1980;9:189-200.

6. Consolaro A. Caracterização microscópica de folículos pericoronários de dentes não-irrompidos e parcialmente irrompidos; Sua relação com a idade [Doctoral Thesis]. Bauru: Faculdade de Odontologia de Bauru Universidade de São Paulo. 1987.

7. Santamaria J, Arteagoitia I. Radiologic variables of clinical significance in the extraction of impacted mandibular third molars. Oral Surg Oral Med Oral Pathol Oral Radiol Endod 1997;84:469-473.

8. Miller CS, Bean LR. Periocoronal radiolucencies with and without radiopacities. Dent Clin North Am 1994;38:51-61.

9. Nolla CM. The development of the permanent teeth. J Dent Child 1960;27:254-260.

10. Andrade ESS. Estudo histológico de folículos pericoronários de dentes inclusos. Recife: Universidade Federal de Pernambuco [MSc Thesis]; 1999.

11. Daley TD, Wysocki GP. The small dentigerous cyst. A diagnostic dilemma. Oral Surg Oral Med Oral Pathol Oral Radiol Endod 1995;79:77-81.

12. Glosser JW, Campbell JH. Pathologic change in soft tissues associated with radiographically "normal" third molar impactions. Br J Oral Maxillofac Surg 1999;37:259-260.

13. Curran AE, Damm DD, Drummond JF. Pathologically significant pericoronal lesions in adults: Histopathologic evaluation. J Oral Maxillofac Surg 2002;60: 613-617.

14. SLATER LJ. Dentigerous cyst versus dental follicle. Br J Oral Maxillofac Surg 2000;38:402.

15. Adelsperger J, Campbell JH, Coates DB, Summerlin DJ, Tomich CE. Early soft tissue pathosis associated with third molars without pericoronal radiolucency. Oral Surg Oral Med Oral Pathol Oral Radiol Endod 2000;89:402-406.

16. Damante JH, Fleury RN. Contribuição para o diagnóstico do pequeno cisto dentígero ou cisto paradentário. Pesqui Odontol Bras 2001;15:238-246.

17. CostaFilho JZ. Avaliação radiográfica e histológica dos folículos pericoronários dos terceiros molares inclusos com rizogênese incompleta [MSc Thesis]. Camaragibe: Faculdade de Odontologia de Pernambuco, Universidade de Pernambuco. 2001.

18. Garrocho AA, Loyola AM, Gomez RS, Figueiredo HS. Dos remanescentes epiteliais na cápsula de cistos dentígeros. Arq Cent Estud Curso Odontol 1988;25:53-60.

19. Assael LA. Impacted teeth: Reflections on Curran, Kugelberg, and Rood. J Oral Maxillofac Surg 2002;60:611-612. 